\title{
DNA de alta qualidade isolado a partir do córtex de Euterpe edulis Mart. (Arecaceae)
}

\author{
DNA of high quality isolated from the cortex of Euterpe edulis Mart. (Arecaceae)
}

\author{
Marina Santos Carvalho, Luina Ribeiro Noia ${ }^{\mathrm{II}}$, Marcia Flores da Silva Ferreira ${ }^{\mathrm{III}}$, Adésio Ferreira $^{\mathrm{IV}}$
}

\begin{abstract}
Resumo
Euterpe edulis (palmiteiro-juçara) é uma arbórea de porte alto que ocorre naturalmente em florestas da Mata Atlântica e Cerrado. Por estas características é difícil coletar folhas jovens, sadias e frescas para obtenção de DNA genômico de boa qualidade para a espécie, necessárias para estudos de biologia molecular. Visando facilitar coletas a campo de material biológico, neste estudo foi proposto o isolamento de DNA a partir de tecidos vegetais do córtex. Foi comparado o DNA genômico obtido a partir de dois tipos de tecido vegetal, sendo estes, folhas jovens oriundas de mudas e do córtex de plantas adultas. A integridade do DNA obtido foi confirmada por eletroforese, revelando DNA genômico com pouca degradação e a qualidade da purificação foi verificada pelos critérios de razões de absorbâncias de $260 / 280 \mathrm{~nm}$ e $260 / 230 \mathrm{~nm}$, apresentando padrão similar nos dois tipos de tecidos avaliados. As concentrações de DNA em folha variaram de 81,9 a $310,1 \mathrm{ng} / \mu \mathrm{L}$, e no córtex, de 105,2 a $404,8 \mathrm{ng} / \mu \mathrm{L}$. A confirmação da qualidade do DNA obtido foi determinada por amplificação de microssatélites nos quais os produtos apresentaram bandas definidas para os dois materiais vegetais. Assim, o DNA genômico isolado a partir do córtex de Euterpe edulis constitui um tecido vegetal adicional para obtenção de DNA genômico de igual qualidade, quantidade e integridade que o obtido de folhas, com a vantagem da coleta ser facilitada a campo.
\end{abstract}

Palavras-chave: Palmiteiro-juçara; Estipe; Isolamento de DNA; Amplificação por PCR

\begin{abstract}
Euterpe edulis is an arboreal species of high size that occurs naturally in the Atlantic Forest and in 'Cerrado' forests. For these characteristics, it is difficult to collect young, healthy and fresh leaves to obtain the genomic DNA of sufficient quality for the species, required for molecular biology studies. To facilitate the collection of biological material field, this study proposed the isolation from plant tissue in the cortex. Isolation and analyzes were carried out compared with the DNA obtained from young leaves coming from plants and tissue of the cortex of adult plants. The integrity of the DNA obtained was confirmed by electrophoresis, revealing the genomic DNA degradation and the low quality of the purification was checked by absorbance ratios criteria 260/280 nm and 260/230 nm, with a similar pattern in both types of tissues evaluated. DNA concentrations ranged from 81.9 to $310.1 \mathrm{ng} / \mu 1$ and cortex, from 105.2 to $404.8 \mathrm{ng} / \mu \mathrm{l}$. The confirmation of the quality of the DNA obtained was determined by microsatellite amplification, where the products showed bands defined for both plant materials. Thus, the genomic DNA isolated from the cortex of Euterpe edulis, constitutes an additional plant tissue to obtain a genomic DNA of equal quality, quantity and integrity of the obtained sheets with the advantage of the collecting being facilitated in the field.
\end{abstract}

Keywords: Heart of palm; Stipe; DNA isolation; PCR Amplification

\footnotetext{
I Bióloga, MSc., Doutoranda do Programa de Pós-Graduação em Genética e Melhoramento, Centro de Ciências Agrárias e Engenharias, Universidade Federal do Espírito Santo, Alto Universitário, s/n, Bairro Guararema, CEP 29500-000, Alegre (ES), Brasil. marinasantosufes@ gmail.com (ORCID: 0000-0003-1541-6634)

II Engenheira Agrônoma, MSc., Centro de Ciências Agrárias e Engenharias, Universidade Federal do Espírito Santo, Alto Universitário, s/n, Bairro Guararema, CEP 29500-000, Alegre (ES), Brasil. noia.luina@gmail.com (ORCID: 0000-0001-7051-2747)

III Bióloga, Dr., Professora do Departamento de Biologia, Centro de Ciências Humanas e Naturais, Universidade Federal do Espírito Santo, Alto Universitário, s/n, Bairro Guararema, CEP 29500-000, Alegre (ES), Brasil. mfloressf@gmail.com (ORCID: 0000-0003-1541-6634)

Iv Agrônomo, Dr., Professor de Produção Vegetal, Centro de Ciências Agrárias e Engenharias, Universidade Federal do Espírito Santo, Alto Universitário, s/n, Bairro Guararema, CEP 29500-000, Alegre (ES), Brasil. adesioferreira@gmail.com (ORCID: 0000-0002-7000-1725)
} 


\section{Introdução}

Diferentes ferramentas de biologia molecular demandam DNA genômico de alta qualidade. Especificamente, os métodos que utilizam marcadores moleculares de DNA utilizados em estudos de genética de populações (KALIA et al., 2011), conservação de espécies, fluxo gênico, história demográfica e eventos de hibridação (OUBORG et al., 2010).

Para isto, protocolos de isolamento de DNA em diferentes espécies precisam ser avaliados (CINGILLI; AKÇIN, 2005) para a obtenção de DNA de qualidade e em quantidade satisfatórias, geralmente obtidas a partir de folhas jovens e sadias de espécies vegetais pelo método CTAB (DOYLE; DOYLE, 1990; AHMED et al., 2009). A extração de DNA a partir do caule também é relatada, no entanto, considerada difícil devido à presença de proteínas, polissacarídeos e compostos fenólicos que atuam como fortes inibidores de extração de DNA (FINKELDEY; LEINEMANN; GAILING, 2010).

A extração do DNA do caule de arbóreas é importante devido à dificuldade de obtenção de folhas jovens e sadias de plantas altas, como Euterpe edulis (palmiteiro-juçara) que chega a atingir $28 \mathrm{~m}$ de altura na fase adulta (DANELLI; FISCH; VIEIRA, 2016). Análises moleculares desta espécie são importantes para sua conservação, pois esta palmeira sofre intenso extrativismo em virtude da produção do palmito de alto valor comercial (LIMA et al., 2008, SHIMIZU et al., 2011). Euterpe edulis também é uma espéciechave da Mata Atlântica, pois seus frutos amadurecem em época de escassez de alimentos na floresta e, portanto, são consumidos por grande número de aves e mamíferos (REIS; KAGEYAMA, 2000; GENINI; GALETTI; MORELLATO, 2009). Os frutos desta espécie têm apresentado destaque comercial devido ao sabor, propriedades nutricionais e alta atividade antioxidante (INÁCIO et al., 2013).

Como é uma espécie monocotiledônea - família Arecaceae - Euterpe edulis só desenvolve crescimento primário, com caule típico da família, chamado estipe (TOMLINSON; HORN; FISHER, 2011; JURA-MORAWIEC; TULIK; IQBAL, 2015). Neste caso, é possível retirar uma pequena porção do córtex para obtenção de material vegetal com células possíveis de se extrair DNA genômico de modo alternativo ao uso de folhas, viabilizando a coleta e transporte do material com baixos riscos de perda e contaminação. Essa alternativa facilita a obtenção de material genético em espécies florestais monocotiledôneas de difícil acesso. Em dicotiledôneas tal metodologia seria dificultada devido ao desenvolvimento do crescimento secundário que resulta em aumento em espessura, cuja porção externa, o súber ou cortiça, é composto de células mortas, infladas e que apresentam paredes celulares dotadas de suberina (BERNARDS, 2002).

Neste trabalho objetivou-se avaliar a extração de DNA a partir do córtex de Euterpe edulis, visando facilitar coletas de material vegetal a campo.

\section{Materiais e Métodos}

Material vegetal

Figura 1 - Coleta de material para extração do DNA. A) Estipe. B) Fragmento retirado do estipe indicando o córtex.

Figure 1 - Material collection for DNA extraction. A) Stipe. B) Removed the stem fragment indicating the cortex.

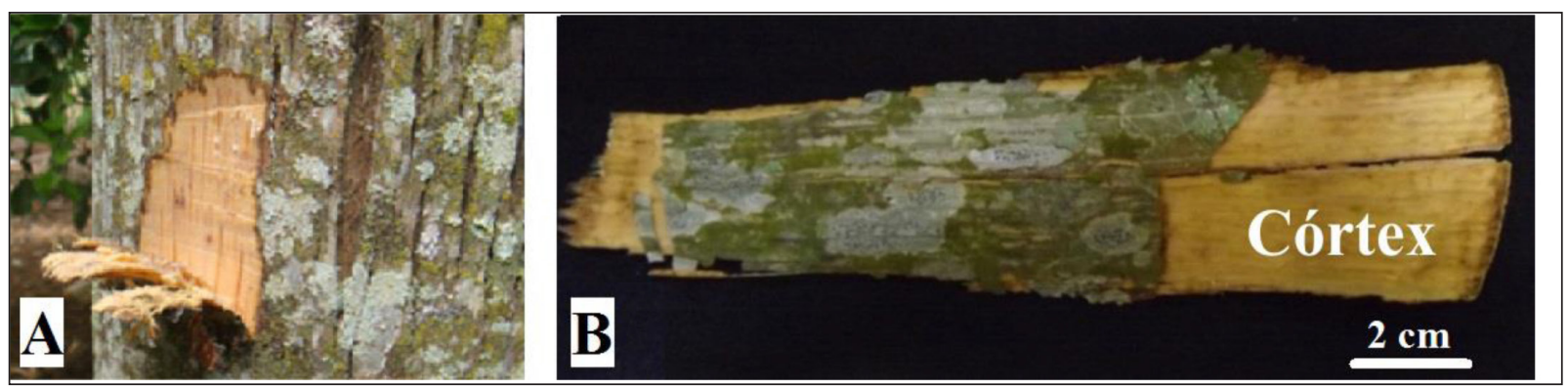

Ci. Fl., Santa Maria, v. 29, n. 1, p. 396-402, jan./mar., 2019 
Para a obtenção das amostras vegetais do córtex de Euterpe edulis, foram retirados pequenos fragmentos do estipe de cada planta adulta, sem causar danos aos indivíduos. As plantas foramcoletadas em Alegre - ES (Figura 1). Amostras vegetais de folhas jovens foram obtidas a partir de mudas cultivadas em casa de vegetação. Material vegetal de sete indivíduos foi amostrado para cada tipo de material vegetal. Os dois tipos de tecido vegetal, córtex e folhas, foram mantidos em sacos de papel em temperatura ambiente contendo sílica gel por 24 horas, visando simular a coleta em condição de campo (CHASE; HILLS, 1991).

Extração, quantificação e amplificação do DNA genômico

A extração do DNA genômico foi realizada através de uma raspagem do córtex, utilizando-se 300 $\mathrm{mg}$ de tecido vegetal, em seguida seguiu-se os procedimentos do protocolo baseado no método CTAB (Brometo de cetiltrimetil amônio) (DOYLE; DOYLE, 1990) modificado pelo CENARGEN (Embrapa Recursos Genéticos e Biotecnologia) (FERREIRA; GRATTAPAGLIA, 1998).

\section{Tabela 1 - Primers microssatélites utilizados.}

Table 1 - Used microsatellite primers.

\begin{tabular}{|c|c|c|c|c|}
\hline Microssatélites & Sequência 5' - 3' & Motivo & $\begin{array}{c}\text { Variação no } \\
\text { tamanho de alelos } \\
(\mathrm{pb})\end{array}$ & $\begin{array}{l}\text { Temperatura } \\
\text { de anelamento } \\
\left({ }^{\circ} \mathrm{C}\right)\end{array}$ \\
\hline EE8 & $\begin{array}{l}\text { F: GTATTCCAATGTGCTCACAG } \\
\text { R: GTGCAGTAGGCTTCTAGTACC }\end{array}$ & $(\mathrm{AG})_{20}$ & $98-127$ & 58 \\
\hline EE23 & $\begin{array}{l}\text { F: GTTCTGCGATTCATACTCCTG } \\
\text { R: TACGAACCAAGATGGAGCAA }\end{array}$ & $(\mathrm{A})_{14}(\mathrm{AG})_{23}$ & $100-123$ & 58 \\
\hline EE32 & $\begin{array}{c}\text { F: CCGCCTGGTGAGCCTCT } \\
\text { R: CAGTGCACCAAGGAACTCCAT }\end{array}$ & $(\mathrm{AG})_{20}$ & $204-249$ & 62 \\
\hline EE43 & $\begin{array}{l}\text { F: GCGAAAGGCTAACAACGTTAT } \\
\text { R: AGCGAACCAACCAAGAAGAC }\end{array}$ & $(\mathrm{AG})_{16}$ & $100-105$ & 56 \\
\hline EE45 & $\begin{array}{l}\text { F: AAAGAAATTGGCGTGACATC } \\
\text { R: AACCAGTCTTCTCCCTCTCG }\end{array}$ & $(\mathrm{AG})_{28}$ & $100-151$ & 56 \\
\hline EE47 & $\begin{array}{l}\text { F: CGAAATCAATGGTTTCAGTG } \\
\text { R: AATTATTGTTGTGGGCAGC }\end{array}$ & $(\mathrm{AG})_{20}$ & $220-236$ & 56 \\
\hline
\end{tabular}

A quantificação do DNA foi realizada utilizando o espectrofotômetro NanoDrop 2000 (Thermo Scientific). O rendimento foi determinado por medições da absorbância a 260, 280 e $230 \mathrm{~nm}$. A pureza do DNA foi determinada pela razão de absorbâncias 260/280 (PASAKINSKIENĖ; PASAKINSKIENĖ, 1999; WEISING et al., 2005) e 260/230 (STEFFAN et al., 1988; GLASEL, 1995; MANCHESTER, 1996). A integridade do DNA foi verificada em eletroforese de gel de agarose $0,8 \%$ corado com $0,25 \mu \mathrm{g} /$ $\mathrm{ml}$ de brometo de etídio em TBE $1 \mathrm{X}$ e fotografada sob luz UV.

Em seguida foram amplificados microssatélites por PCR (Polymerase Chain Reaction), utilizando seis pares de primers SSR desenvolvidos e otimizados para Euterpe edulis por Gaiotto, Brondani e Grattapaglia (2001) (Tabela 1). A reação de volume de $13 \mu \mathrm{L}$ foi composta de: $30 \mathrm{ng}$ de DNA genômico; $1 \mathrm{X}$ de tampão I0 (phoneutria); 0,2 $\mu \mathrm{M}$ de cada primer (forward e reverse); $1,5 \mathrm{mM} \mathrm{MgCl}_{2} ; 0,25 \mathrm{mM} \mathrm{dNTPs}$; e 1,2 U de Taq DNA polimerase. A reação foi realizada em termociclador Veriti (Applied Biosystems). $\mathrm{O}$ programa de amplificação foi de $94^{\circ} \mathrm{C}$ por quatro minutos; 30 ciclos compostos por $94^{\circ} \mathrm{C}$ por um minuto, temperatura de anelamento (específica de cada primer) por um minuto; $72^{\circ} \mathrm{C}$ por um minuto; uma extensão final de $72^{\circ} \mathrm{C}$ por 7 minutos.

Os produtos de amplificação foram separados por eletroforese em géis de agarose $1,5 \%$ corados 
com gel red(1:500) em tampão TBE 1X. Após a eletroforese, os géis foram fotografados sob luz UV. Os dois tipos de amostras testadas para extração de DNA foram avaliados utilizando-se o teste $\mathrm{F}$ a $5 \%$ de

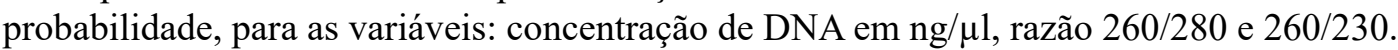

\section{Resultados e Discussão}

Nesse estudo foi verificada a eficiência do protocolo de extração de DNA baseado no método CTAB, usando como material o córtex (localizado no estipe) de Euterpe edulis. As concentrações de DNA obtidas (em ng/ $\mu \mathrm{L}$ ) pela extração do DNA genômico, nos dois tipos de materiais vegetais foram semelhantes, não diferindo estatisticamente pelo teste $\mathrm{F}(\mathrm{P}>0,01)$. Na folha variaram de 81.9 a 310.1 $\mathrm{ng} / \mu \mathrm{L}$ e no córtex de 105.2 a $404.8 \mu \mathrm{g} / \mu \mathrm{L}$ (Tabela 2). A razão das absorbâncias de A260/A280 nm entre 1,8-2,0 indica um elevado grau de pureza de amostras de DNA, quanto à contaminação com proteína que apresenta absorbância próximo a 280nm (PASAKINSKIENĖ; PASAKINSKIENE், 1999; WEISING et al., 2005). Neste estudo, esta razão variou de 1,94 a 2,02 para folhas, e de 1,90 a 1,97 para o córtex, indicando a pureza do DNA em ambos os materiais vegetais utilizados. A razão de absorbâncias entre A260/A230 quando apresenta valores inferiores a 1,8 são indicativos de quantidades significativas de contaminação da amostra com sais, polissacarídeos e fenol (STEFFAN et al., 1988; GLASEL, 1995; MANCHESTER, 1996). Nos dois tipos de amostras, os valores obtidos foram próximos ou superiores a 1,8 para esta razão (em folhas entre 1,76 a 2,05; no córtex entre 1,96 a 2,03), reafirmando a pureza do DNA e mostrando pouca diferença entre utilizar material foliar ou córtex. Entretanto, os dois tipos de amostras apresentaram diferenças estatisticamente significativas pelo teste $\mathrm{F}(\mathrm{P}<0,01)$, sendo a melhor qualidade obtida neste parâmetro para o DNA obtido do córtex (Tabela 2).

\section{Tabela 2 - Média e desvio padrão da concentração e pureza de DNA genômico extraído a partir de folha e córtex de Euterpe edulis.}

Table 2 - Mean and standard deviation of the concentration and purity of genomic DNA extracted from leaf and cortex from Euterpe edulis.

\begin{tabular}{lccc}
\hline Material & DNA Genômico total $(\mathbf{n g} / \boldsymbol{\mu l})^{\mathbf{n s}}$ & $\mathbf{A 2 6 0 / A 2 8 0 * *}$ & $\mathbf{A 2 6 0}^{*} \mathbf{A 2 3 0} * *$ \\
\hline Folha & $194,56 \pm 73,59$ & $1,97 \pm 0,03$ & $1.89 \pm 0,12$ \\
Córtex & $239,90 \pm 99,11$ & $1,94 \pm 0,03$ & $2.01 \pm 0,07$ \\
\hline
\end{tabular}

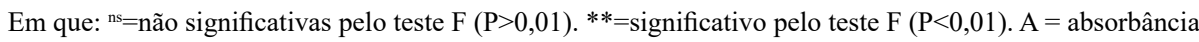

A eletroforese em gel de agarose $(0,8 \%)$ mostrou bandas de DNA genômico bem definidas (Figura 2) e de elevada massa molecular, indicando a integridade do DNA.

A extração de DNA a partir do caule é considerada difícil devido à presença de proteínas, polissacarídeos e compostos fenólicos que contaminam o DNA (FINKELDEY; LEINEMANN; GAILING, 2010) e inibem a atividade da polimerase (KARACA et al., 2005; SINGH; KUMAR, 2012). Contudo, os critérios de qualidade pelo uso de absorbância demonstram que o protocolo usado elimina estes interferentes durante a extração, tendo como produto final um DNA de qualidade. Além disso, a amplificação de fragmentos do DNA por PCR confirmou esta qualidade pela obtenção de amplicons bem definidos no gel de agarose, tanto com DNAs extraídos de folha, quanto de córtex (Figura 3).

$\mathrm{O}$ alto porte de Euterpe edulis na fase adulta, cerca de $30 \mathrm{~m}$ de altura (DANELLI; FISCH; VIEIRA, 2016), dificulta a coleta de material vegetal foliar de indivíduos em populações naturais. A obtenção de DNA genômico a partir da estipe, viabiliza a coleta de material vegetal em campo para a realização de estudos moleculares. O protocolo utilizado na extração do DNA foi baseado no método CTAB (DOYLE; DOYLE, 1990) modificado pelo Embrapa Recursos Genéticos e Biotecnologia (CENARGEN) (FERREIRA; GRATTAPAGLIA, 1998). Esse método é relativamente simples e usado rotineiramente em 
estudos genéticos de espécies vegetais, entretanto, segue o princípio do uso como material de extração de folhas jovens, frescas, sem danos mecânicos ou sinais de doença (FERREIRA; GRATTAPAGLIA, 1998).

Figura 2 - Integridade do DNA genômico obtido em gel de agarose $0,8 \%$ e concentração de genômico total. A) Amostras de DNA extraído de folha. B) Amostras de DNA extraído de córtex.

Figure 2 - Integrity of genomic DNA on $0.8 \%$ agarose gel. A) DNA samples extracted from leaf. B)

DNA samplesextracted from the cortex.

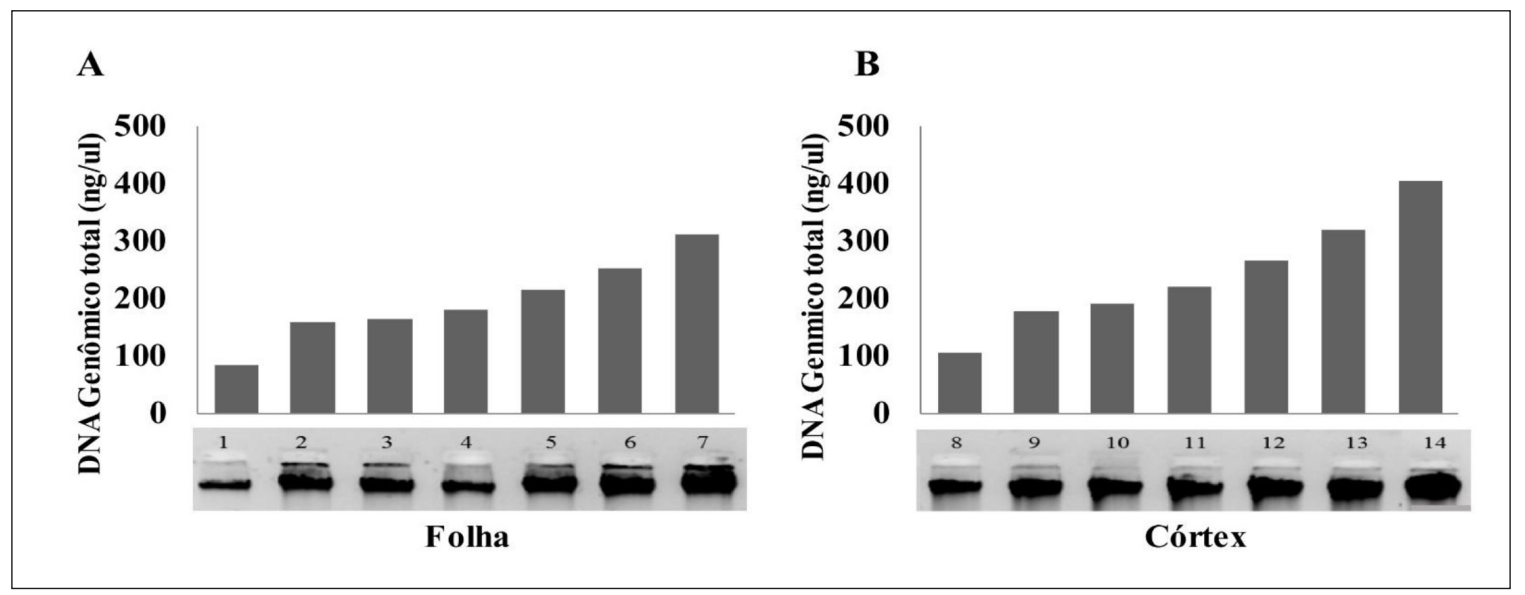

Figura 3 - Eletroforese em gel de agarose 1,5\% mostrando os perfis de amplificação dos primers EE23, EE32 e EE43 em Euterpe edulis. Marcador de 50 pb.

Figure 3 - Electrophoresis in 1.5\% agarose gel showing the amplification profiles of primers EE23, EE32 and EE43 in Euterpe edulis. Marker 50 bp.

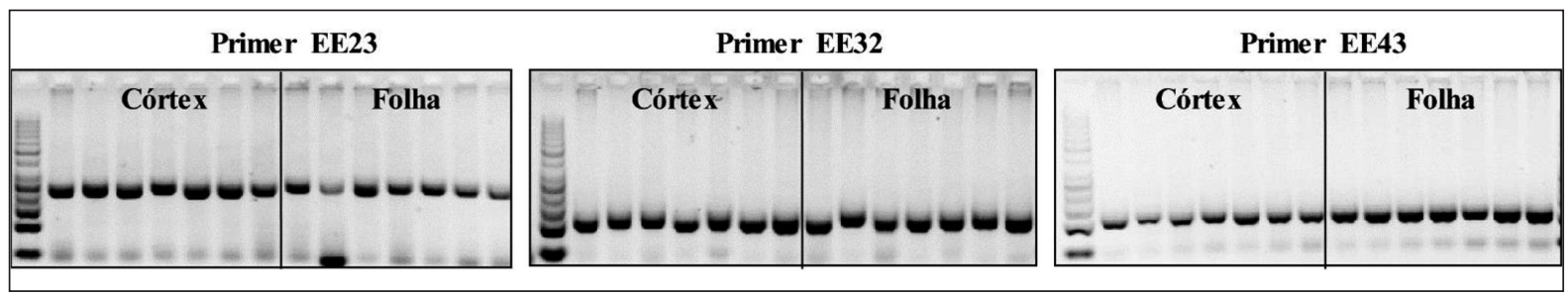

\section{Conclusões}

O protocolo utilizado permitiu obter DNA genômico em boa quantidade e sem contaminantes a partir do córtex, com qualidade semelhante ao obtido de folhas. O córtex é uma opção menos trabalhosa, rápida, reprodutível, simples, de baixo custo e eficaz para o isolamento de DNA em estudos de populações naturais. Esta forma de obtenção de DNA de boa qualidade pode ser testada em outras espécies tanto da família quanto as que apresentam caule com ausência de crescimento secundário.

\section{Agradecimentos}

Agradecemos à Fundação de Amparo e Pesquisa do Espírito Santo (FAPES), Coordenação de Aperfeiçoamento de Pessoal de Nível Superior (CAPES) e ao Conselho Nacional de Desenvolvimento Científico e Tecnológico (CNPq). 


\section{Referências}

AHMED, I. et al. High-quality plant DNA extraction for PCR: an easy approach. Journal of Applied Genetics,Poznan, v. 50, n. 2, p. 105-107, 2009.

BERNARDS, M. A. Demystifying suberin. Canadian Journal of Botany, Ottawa, v. 80, n. 3, p. 227-240, 2002.

CINGILLI, H.; AKÇIN, A. High quality DNA isolation method for chickpea genotypes. Turkish Journal of Biology, Ankara, v. 29, n. 1, p. 1-5, 2005.

DANELLI, M. F.; FISCH, S. T. V.; VIEIRA, S. A. Análise da estrutura e biomassa florestal de áreas de colheita de frutos de juçara (Euterpeedulis Mart.) no litoral norte e serra do ar-SP. Ciência Florestal, Santa Maria, v. 26, n. 3, 2016.

DOYLE, J. J.; DOYLE, J. L. Isolation of plant DNA from fresh tissue. Focus, Rockville, v. 12, n. 27, p. 13-15, 1990.

FERREIRA, M. E.; GRATTAPAGLIA, D. Introdução ao uso de marcadores moleculares em análise genética.3. ed. Brasília: EMBRAPA; CENARGEN, 1998. 220 p.

FINKELDEY, R.; LEINEMANN, L.; GAILING, O. Molecular genetic tools to infer the origin of forest plants and wood. Applied Microbiology and Biotechnology, Berlin, v. 85, n. 5, p. 1251-1258, 2010 .

GAIOTTO, F. A.; BRONDANI, R. P. V.; GRATTAPAGLIA, D. Microsatellite markers for heart of palm Euterpe edulis and E. oleracea Mart. (Arecaceae). Molecular Ecology Notes, Oxford, v. 1, n. 1/2, p. 86-88, 2001.

CHASE, M. W.; HILLS, H. H. Silica gel: an ideal material for field preservation of leaf samples for DNA studies. Taxon, Viena, v. 40, n. 2, p. 215-220, 1991.

GENINI, J.; GALETTI, M.; MORELLATO, L. P. C. Fruiting phenology of palms and trees in an Atlantic rainforest land-bridge island. Flora, Jena, v. 204, n. 2, p. 131-145, 2009.

GLASEL, J. A. Validity of nucleic acid purities monitored by $260 \mathrm{~nm} / 280 \mathrm{~nm}$ absorbance ratios. BioTechniques, New York, v. 18, n. 1, p. 62-63, 1995.

INÁCIO, M. R. C. et al. Total anthocyanin content determination in intact açaí (Euterpeoleracea Mart.) and palmiteiro-juçara (Euterpe edulis Mart.) fruit using near infrared spectroscopy (NIR) and multivariate calibration. Food Chemistry,Barking, v. 136, n. 3, p. 1160-1164, 2013.

JURA-MORAWIEC, J.; TULIK, M.; IQBAL, M. Lateral meristems responsible for secondary growth of the monocotyledons: a survey of the state of the art. Botanical Review, Bronx, v. 81, n. 2, p. 150-161, 2015.

KALIA, R. K. et al. Microsatellite markers: an overview of the recent progress in plants. Euphytica, Wageningen, v. 177, n. 3, p. 309-334, 2011.

KARACA, M. et al. Coisolation of genomic and organelle DNAs from 15 genera and 31 species of plants. Analytical Biochemistry, New York, v. 343, p. 353-355, 2005.

LIMA, L. S. H. Crescimento de mudas de Euterpe edulis Martius em resposta a diferentes doses de fósforo. Ciência Florestal, Santa Maria, v. 18, n. 4, p. 461-470, 2008.

MANCHESTER, K. A. Use of UV methods for measurement of protein and nucleic acid concentrations.

BioTechniques, New York, v. 20, n. 6, p. 968-970, 1996. 
OUBORG, J. et al. Conservation genetics in transition to conservation genomics. Trends in Genetics, Cambridge, v. 26, n. 4, p. 177-187, 2010.

PASAKINSKIENĖ, I.; PASAKINSKIENE, V. Floral meristems as a source of enhanced yield and quality of DNA in grasses. Plant Cell Reports, Berlin, v. 18, n. 6, p. 490-492, 1999.

REIS, A.; KAGEYAMA, P. Y. Dispersão de sementes do palmiteiro (Euterpe edulis Martius - Palmae). Sellowia: Anais Botánicos do HBR, Itajaí, v. 49, n. 49-52, p. 60-92, 2000.

SHIMIZU, M. M. et al. Enzyme characterisation, isolation and cDNA cloning of polyphenol oxidase in the hearts of palm of three commercially important species. Plant Physiology and Biochemistry, Paris, v. 49, n. 9, p. 970-977, 2011.

SINGH, V.; KUMAR, V. An optimised method of DNA isolation from highly mucilage rich okra (Abelmoschus esculentus L.) for PCR analysis. Pelagia Research Library,Udaipur, v. 3, p. 1809-1813, 2012.

STEFFAN, R. J. et al. Recovery of DNA from soils and sediments. Applied and Environmental Microbiology, Washington, v. 54, n. 12, p. 2908-2915, 1988.

TOMLINSON, P. B.; HORN, J. W.; FISHER, J. B.Anatomy of palms (Arecaceae - Palmae). New York: Oxford University Press, 2011.

WEISING, K. et al. DNA fingerprinting in plants: principles, methods, and applications. [S.1.]: CRC press, 2005. 444 p. 